\title{
UTJECAJ ISPUNA OD BETONA S OPEKARSKIM LOMOM KAO AGREGATOM NA POTRESNI ODZIV KRATKIH STUPOVA
}

\author{
Ivan Kraus \\ Sveučilište Josipa Jurja Strossmayera u Osijeku, Građevinski fakultet Osijek, asistent \\ Martina Paradžiković \\ Sveučilište Josipa Jurja Strossmayera u Osijeku, Građevinski fakultet Osijek, univ.bacc.ing.aedif. \\ Ivana Miličević \\ Sveučilište Josipa Jurja Strossmayera u Osijeku, Građevinski fakultet Osijek, asistentica
}

\begin{abstract}
Sažetak: Mnoga izvješća načinjena nakon obilazaka potresom pogođenih područja pokazuju da su kratki stupovi vrlo osjetjjivi elementi te da su izvor oštećenja na zgradama pogođenim potresom. Osim toga, pregledom literature je ustanovljeno da djelomični nekonstrukcijski zidani ispun, u usporedbi s betonskim ispunima, ima manje štetan utjecaj na kratke stupove. Ova spoznaja je ukazala na mogućnost primjene opekarskog loma (lom opeke i crijepa) kao agregata za beton, čime bi se dodatno podržao održivi razvoj. U radu je prikazano numeričko istraživanje utjecaja ispuna od betona $s$ opekarskim lomom kao agregatom na potresni odziv kratkih armiranobetonskih stupova, kao i proračun i konstruiranje kratkih stupova, sličan onome za vezne grede zidova s otvorima. Linearno-elastični modalni proračun spektrima odziva proveden je na tropoljnim armiranobetonskim okvirima visine četiri i sedam katova. Mehanička svojstva betona s opekarskim lomom kao agregatom, opisana i korištena u ovom istraživanju, određena su laboratorijskim ispitivanjima provedenima na Građevinskom fakultetu Osijek.
\end{abstract}

Ključne riječi: beton, opekarski lom, potresni odziv, kratki stup, gospodarenje otpadom

\section{EFFECT OF INFILLS MADE OF CONCRETE CONTAINING CRUSHED BRICKS/TILES ON SEISMIC RESPONSE OF SHORT COLUMNS}

\begin{abstract}
Various post-earthquake reports indicate that short columns are vulnerable structural members and significant source of serious earthquake damage. Furthermore, reviewing the literature, it was observed that nonstructural partial brick infills, comparatively to partial concrete infills, have less harmful effects on short columns. This put a new perspective on the use of crushed bricks and tiles as concrete aggregate with the additionally benefit of providing a sustainable management of such material. This paper discusses a numerical study on the effect of infills made of concrete containing crushed bricks and tiles on the response of short reinforced-concrete columns. In addition, this paper presents an approach for the analysis and design of short columns, similar to that of tie beams. Linear elastic analysis was carried out on four- and seven-story three-bay reinforced-concrete frames using modal response spectrum analysis. Mechanical properties of concretes containing crushed bricks and tiles determined by laboratory testing at Faculty of Civil Engineering Osijek are described and used in this study.
\end{abstract}

Key words: concrete, crushed brick and tile, seismic response, short column, waste management 


\section{Uvod}

Mnoga izvješća načinjena nakon obilazaka potresom pogođenih područja pokazuju da su kratki stupovi vrlo osjetljivi elementi te da su izvor ozbiljnih oštećenja na zgradama pogođenim potresom (slika 1).

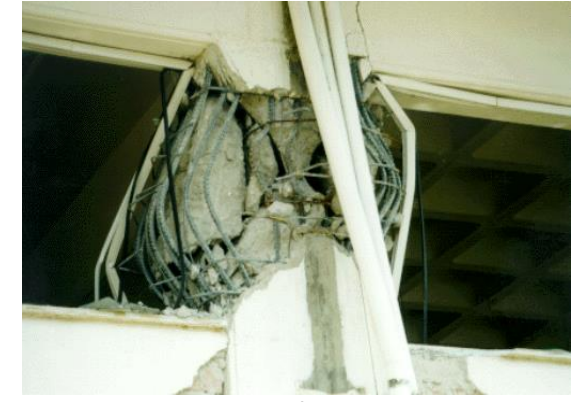

a)

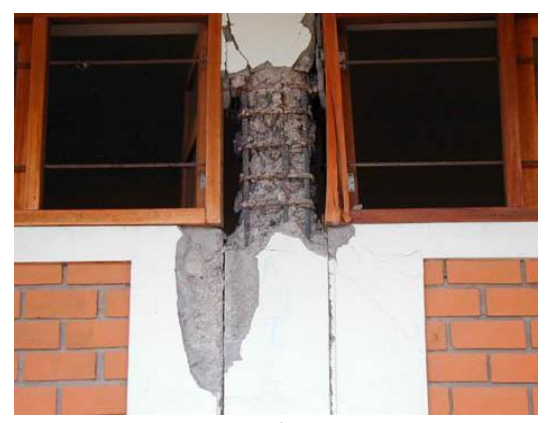

b)

Slika 1 - Primjeri oštećenja kratkih stupova: a) detalj peterokatnice izgrađene 1997. godine prema Grčkim propisima za proračun konstrukcija otpornih na potres [1]; b) spone $\varnothing 10$ na razmaku od $10 \mathrm{~cm}$ nisu spriječile teška oštećenja na stupu nastala djelovanjem potresa [2]

Ipak, nije rijetkost kratke stupove pronaći čak i u novim zgradama, npr. u zgradama na kosom terenu, zgradama s djelomično ukopanim podrumima, te školama, skladištima, bolnicama, industrijskim i drugim zgradama gdje postoji potreba za visokim parapetima iz arhitektonskih razloga (slika 2), [3], [4], [5].
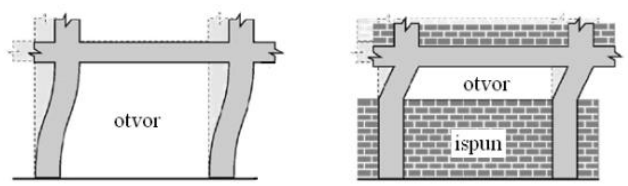

a)

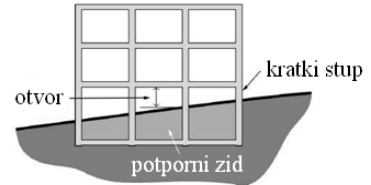

b)

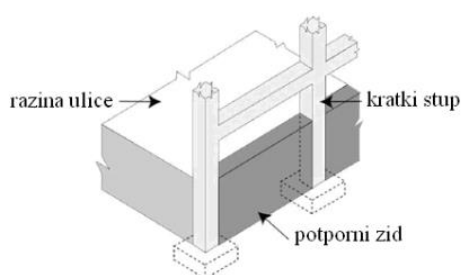

c)

Slika 2 - Primjeri mjesta u zgradama gdje se može pronaći kratki stup, [3]: a) zgrada s okvirima s visokim parapetom; b) zgrada na kosom terenu; c) zgrada s djelomično ukopanim podrumom

Prema navodima u [4], kratki stupovi su oni stupovi kod kojih je posmično naprezanje glavni uzrok sloma, te stupovi s posmičnom vitkošću $a_{\mathrm{s}} \leq 3$. Posmična vitkost se definira kao omjer svijetle visine stupa i dimenzije poprečnog presjeka stupa paralelne sa smjerom djelovanja potresa. Zanimljivo je primijetiti da stup poprečnog presjeka dimenzije $75 \mathrm{~cm}$ i svijetle visine $230 \mathrm{~cm}$, što nije rijetkost za industrijske zgrade, može biti klasificiran kao kratki stup, [4]. Nadalje, izvješća načinjena nakon obilazaka potresom pogođenih područja pokazuju da nekonstrukcijski, ili bolje reći nenamjerno-konstrukcijski djelomični zidani ispun, u usporedbi s betonskim ispunom ima manje štetan utjecaj na kratke armiranobetonske stupove [3]. Ova spoznaja, uz činjenicu da je dokazana mogućnost primjene opekarskog loma (lom opeke i crijepa) kao agregata za beton ([6], [7]), ukazuje na mogućnost izrade nekonstrukcijskog ispuna od betona s opekarskim lomom kao djelomičnom zamjenom prirodnog agregata. Dosadašnja istraživanja provedena na opekarskom lomu kao agregatu pokazuju sljedeće, [6], [7]:

1) zbog velike poroznosti i apsorpcije opekarskog loma nužno je dodavanje plastifikatora ili prethodno vlaženje agregata kako bi se izbjeglo projektiranje sastava betonske mješavine s velikim stupnjem obradivosti;

2) zbog velikog udjela prašinastih čestica u drobljenoj opeci potrebna je dodatna količina vode kako bi se poboljšala obradivost betonske mješavine, što u konačnici rezultira manjom čvrstoćom betona; 
3) gustoća betona s drobljenom opekom je do $17 \%$ manja od gustoće betona s prirodnim agregatom, dok je modul elastičnosti betona s drobljenom opekom do $40 \%$ manji od modula elastičnosti betona $s$ prirodnim agregatom;

4) udio cementa u betonu s drobljenom opekom može biti i do $20 \%$ veći nego kod betona s prirodnim agregatom;

5) skupljanje betona s drobljenom opekom je veće od skupljanja betona s prirodnim agregatom;

6) beton s drobljenom opekom ima znatno veću požarnu otpornost te do 3,5 puta manju toplinsku provodljivost od betona s prirodnim agregatom.

Procjenjuje se da opekarski lom zauzima $12 \%$ ukupnog građevinskog otpada nastalog pri rušenju građevina te da godišnje količine opekarskog loma iznose oko 280.000 tona, [6]. Zabrinjava činjenica da se građevinski otpad nekontrolirano odlaže te da ne postoji razrađen sustav poticanja ugradnje recikliranih materijala, [6]. Kako beton može poslužiti kao spremnik za otpadni građevinski materijal, izradom nekonstrukcijskog ispuna od betona s opekarskim lomom dodatno bi se podržao održivi razvoj. Rad daje prikaz numeričkog istraživanja utjecaja ispuna od betona s opekarskim lomom kao agregatom na potresni odziv kratkih armiranobetonskih stupova, kao i proračun i konstruiranje kratkih stupova, sličan onome za vezne grede zidova s otvorima. Linearno-elastični modalni proračun spektrima odziva je proveden na tropoljnim armiranobetonskim okvirima visine četiri i sedam katova.

\section{Bidijagonalno armiranje kratkih stupova}

Opsežna teorijska i eksperimentalna istraživanja dala su učinkovita načela i metode za konstruiranje i proračun veznih greda zida s otvorima koja su, zbog sličnosti ponašanja kratkih stupova i veznih greda pri djelovanju potresa ([4]), korištena i u ovom radu. Postupak izračuna potrebne količine bidijagonalne (kosa u dva smjera) armature dan je sljedećim izrazom, [4]:

$$
F_{s}=F_{c}=\frac{V_{E d}}{2 \sin \alpha} A_{s} \cdot f_{y d}
$$

odnosno

$$
A_{s}=\frac{V_{E d}}{2 \sin \alpha \cdot f_{y d}}
$$

gdje je $F_{\mathrm{s}}$ vlačna sila, $F_{\mathrm{c}}$ tlačna sila, $V_{E d}$ proračunska poprečna sila stupa za potresnu kombinaciju djelovanja, $\alpha$ kut koji zatvara glavna uzdužna armatura stupa i uzdužna armatura dijagonalnog koša (slika 3 ), $A_{s}$ površina uzdužne armature jednog dijagonalnog koša, $f_{y d}$ proračunska granica popuštanja.
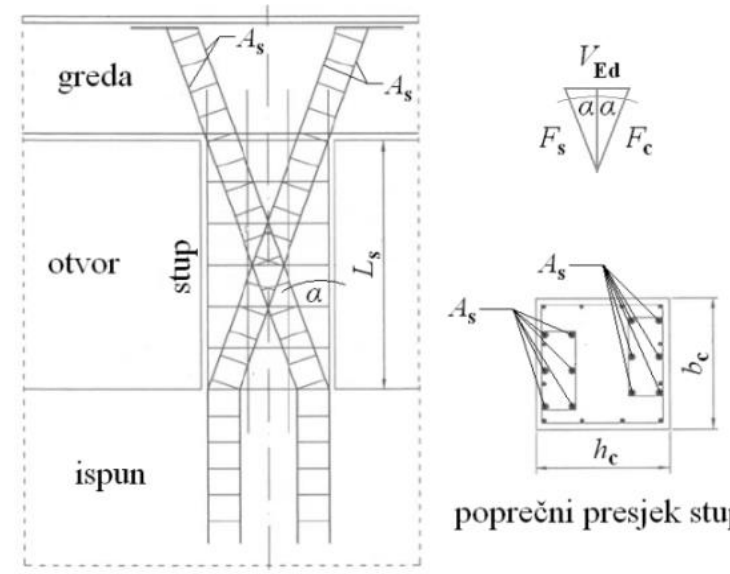

poprečni presjek stupa

Slika 3 - Bidijagonalna armatura kratkog stupa, [4] (sliku obradili autori) 
Kut koji zatvara glavna uzdužna armatura stupa i uzdužna armatura dijagonalnog koša $\alpha$ izračunava se pomoću sljedećeg izraza:

$$
\operatorname{tg} \alpha=\frac{h_{c}-d_{1}-d_{2}}{L_{s}}
$$

gdje je $h_{\mathrm{c}}$ širina poprečnog presjeka stupa u smjeru djelovanja potresa, $d_{1}$ udaljenost vlačnog ruba poprečnog presjeka od težišta vlačne uzdužne armature, $d_{2}$ udaljenost tlačnog ruba poprečnog presjeka od težišta tlačne uzdužne armature, a $L_{s}$ svijetla visina stupa. Poprečna armatura dijagonalnih koševa treba biti proračunana i ugrađena slično armiranju običnog stupa, [4].

\section{$3 \quad$ Numerički modeli}

Linearno-elastični modalni proračun spektrima odziva proveden je na ravninskim, tropoljnim, fasadnim okvirima visine četiri i sedam katova. Kako bi se istraživanje usmjerilo isključivo na utjecaj vrste betona od kojeg su izrađeni parapetni zidovi na odziv stupova ovisno o njihovoj vitkosti, okviri su izdvojeni iz zgrade pravilne u tlocrtu i po visini. Pretpostavljeno je da se zgrada nalazi na izrazito aktivnom potresnom području i to na tlu kategorije $B$, kako je definirano prema europskim propisima ([8]). Osim toga, pretpostavljeno je da je zgrada upeta u temelje ili temeljnu konstrukciju - podrum. Temelji, odnosno temeljna konstrukcija, nisu uzeti u obzir u numeričkom modelu. Numerički proračun je izvršen koristeći programski paket SAP2000 ([9]). Grede i stupovi okvira su modelirani koristeći štapaste konačne elemente duljine redom $0,50 \mathrm{~m} \mathrm{i} \mathrm{0,25} \mathrm{m}$, a ispun je modeliran koristeći tankostijene, plošne, pravokutne konačne elemente dimenzija $0,50 \times 0,25 \mathrm{~m}$. Stropne ploče nisu modelirane, a sudjelujuća širina ploča nije uzeta u obzir prilikom modeliranja poprečnog presjeka greda.

\subsection{Materijal}

Svi nosivi konstrukcijski elementi su izrađeni od normalnog betona razreda $C 30 / 37$, karakteristične tlačne čvrstoće $f_{c k} 30 \mathrm{~N} / \mathrm{mm}^{2}$, modula elastičnosti $E_{\mathrm{cm}} 33000 \mathrm{~N} / \mathrm{mm}^{2}$ te specifične gustoće $\rho_{\mathrm{c}} 2400 \mathrm{~kg} / \mathrm{m}^{3}$. Vrsta betona za izvedbu ispuna je varirana, a njihova svojstva su dana u tablici 1. Mehanička svojstva betona s opekarskim lomom (BOL) odredili su autori ispitivanjima u laboratoriju. Tablica 2 daje prikaz udjela agregata u ukupnom volumenu mješavina betona s opekarskim lomom.

\section{Tablica 1 - Vrste betona korištene za izradu ispuna okvira}

\begin{tabular}{|c|c|c|c|c|c|}
\hline \multicolumn{2}{|c|}{ Oznaka betona } & Izvor svojstava & $f_{c}\left(\mathrm{~N} / \mathrm{mm}^{2}\right)$ & $E_{\mathrm{cm}}\left(\mathrm{N} / \mathrm{mm}^{2}\right)$ & $\rho_{\mathrm{c}}\left(\mathrm{kg} / \mathrm{m}^{3}\right)$ \\
\hline & C 12/15 & {$[11]$} & 12 & 27000 & 2400 \\
\hline C 16/20 & {$[11]$} & 16 & 29000 & 2400 \\
\hline BOL 9 & Laboratorijski & 9 & 10500 & 1800 \\
\hline BOL 15 & Laboratorijski & 15 & 21500 & 2000 \\
\hline
\end{tabular}

Tablica 2 - Udjeli agregata u sastavu mješavina betona s keramičkim lomom

\begin{tabular}{|c|c|c|c|c|c|c|}
\hline \multirow{2}{*}{ Betonska mješavina } & \multicolumn{2}{|c|}{ Opeka } & \multicolumn{2}{c|}{ Crijep } & \multicolumn{2}{c|}{ Dolomit } \\
\cline { 2 - 6 } & $0-4 \mathrm{~mm}$ & $4-16 \mathrm{~mm}$ & $0-4 \mathrm{~mm}$ & $4-16 \mathrm{~mm}$ & $0-4 \mathrm{~mm}$ & $4-16 \mathrm{~mm}$ \\
\hline BOL 9 & $50 \%$ & $50 \%$ & $25 \%$ & $25 \%$ & $25 \%$ & $25 \%$ \\
\hline BOL 15 & $50 \%$ & $0 \%$ & $25 \%$ & $25 \%$ & $25 \%$ & $75 \%$ \\
\hline
\end{tabular}

U nedostatku podataka, za sve betone je pretpostavljena vrijednost Poissonovog omjera v 0,20, [10], [11]. Konstrukcijski elementi su armirani koristeći armaturne šipke razreda B500B, karakteristične granice popuštanja $f_{y} 500 \mathrm{~N} / \mathrm{mm}^{2}$ i modula elastičnosti $E_{\mathrm{s}} 200000 \mathrm{~N} / \mathrm{mm}^{2}$, [12]. Nadalje, pretpostavljeno je da su svi konstrukcijski elementi armirani normalnim udjelom armature, što prema [13] rezultira povećanjem specifičnih težina betona za $100 \mathrm{~kg} / \mathrm{m}^{3}$. Parcijalni koeficijenti sigurnosti za materijal su u skladu s europskim propisima [11]. 


\subsection{Geometrija}

Numerički modeli su prikazani na slici 4. Prema zahtjevu u [8], stropne ploče su izrađene od armiranog betona i debljine su $18 \mathrm{~cm}$. Debljina ispuna okvira odgovara polovini širine poprečnog presjeka stupa i iznosi $25 \mathrm{~cm}$, [10].

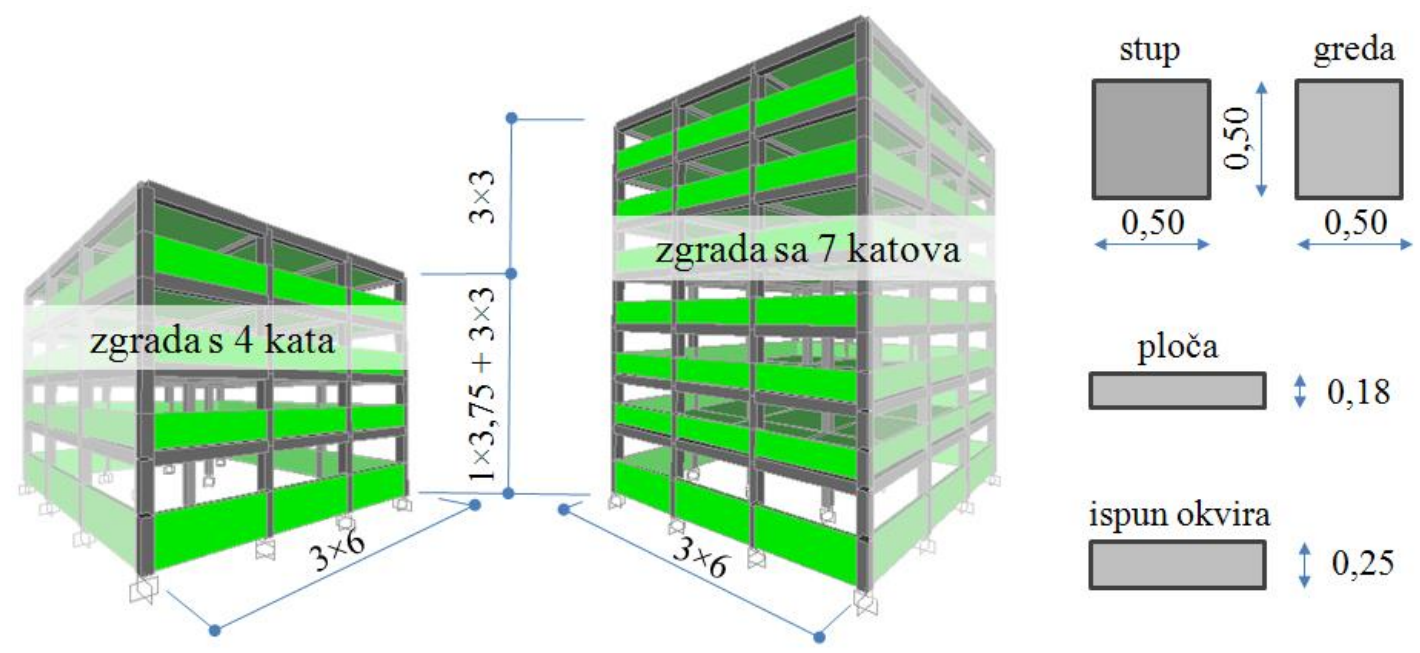

\section{Slika 4 - Geometrija sastavnih elemenata konstrukcije (m)}

Visina ispuna okvira u prizemlju je u funkciji posmične vitkosti kratkog stupa $\alpha_{\mathrm{s}}$ koja je varirana u granicama 1 $-3 \mathrm{~s}$ korakom 0,5 . Visina ispuna okvira viših katova jednaka je polovini visine kata.

\subsection{Opterećenje}

Vertikalno opterećenje uključuje stalno i promjenjivo opterećenje koje je na okvire dodano kako je opisano u [14]. Programski paket [9] korišten za proračun, sam u obzir uzima vlastitu težinu elemenata konstrukcije. Dodatno stalno opterećenje koje uključuje pregradne zidove, slojeve poda te podgled, iznosi $3,35 \mathrm{kN} / \mathrm{m}^{2}$, [12]. Težina greda okomitih na razmatrane okvire uzeta je u obzir kako je opisano u [14]. Uz pretpostavku da su okviri izdvojeni iz školskih zgrada, uporabno opterećenje je uzeto u iznosu od $3,00 \mathrm{kN} / \mathrm{m}^{2}$ prema preporukama u [13]. Promjenjivo opterećenje krovnih ploča usvojeno je prema preporukama u [15] i iznosi $2,00 \mathrm{kN} / \mathrm{m}^{2}$. Potresno opterećenje je zadano u obliku proračunskih spektara odziva. Svaki okvir je opterećen s 4 različita spektra odziva tipa 1, definirana prema europskim propisima [8] (slika 5). Pretpostavljeno je da katovi imaju povezanu zauzetost. Kombinacije opterećenja izrađene su kako je opisano u [14] i u skladu s europskim propisima.

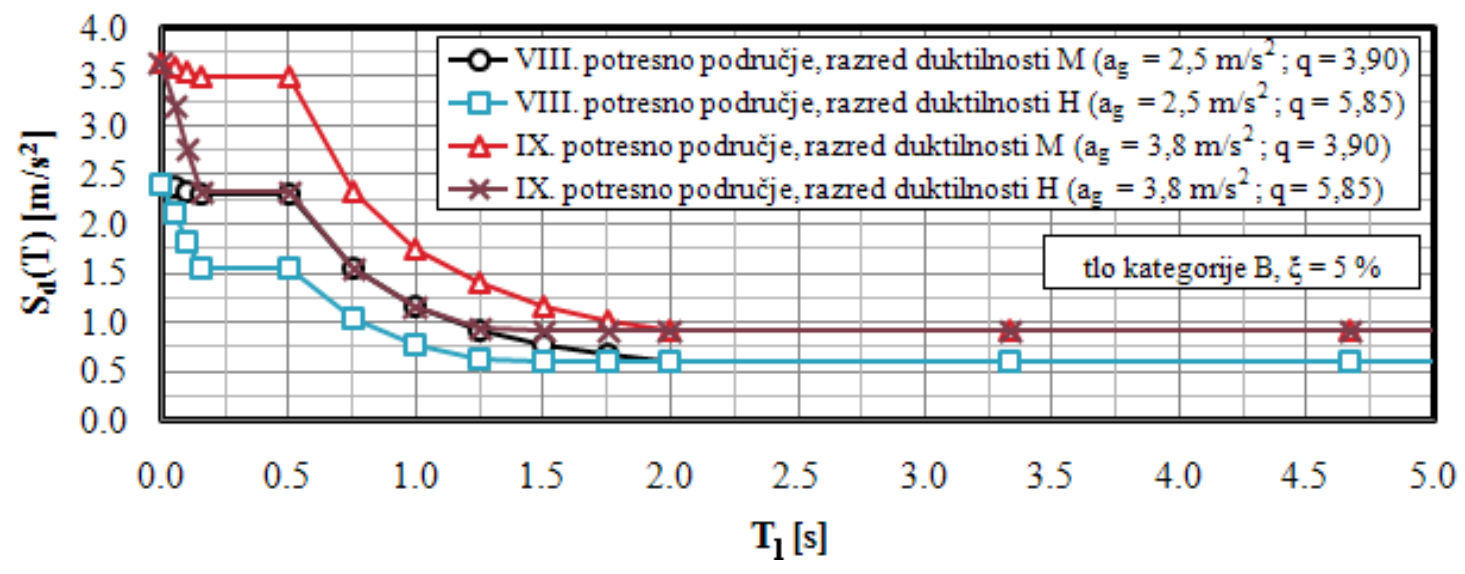

Slika 5 - Proračunski spektri odziva 


\section{Rezultati i diskusija}

Osnovni periodi osciliranja $T_{1}$ okvira kreću se u granicama 0,191 - 0,412 s (tablica 3). Okviri s konvencionalnim betonima imaju manje periode osciliranja, a time i veće ordinate proračunskog spektra $S_{d}(T)$ u usporedbi $s$ okvirima čiji je ispun izrađen od nekonvencionalnih betona. Razlog tomu prvenstveno je veća specifična težina konvencionalnih betona u odnosu na nekonvencionalne betone (tablica 1).

\section{Tablica 3 - Osnovni periodi osciliranja okvira}

\begin{tabular}{|l|c|c|c|c|c||c|c|c|c|c|}
\hline \multirow{2}{*}{$\begin{array}{c}\text { Oznaka betona } \\
\text { ispuna }\end{array}$} & \multicolumn{8}{|c|}{ Osnovni periodi osciliranja (s) } \\
\cline { 2 - 11 } & 1 & \multicolumn{7}{|c|}{ Posmična vitkost okvira s 4 kata } & \multicolumn{5}{c|}{ Posmična vitkost okvira sa 7 katova } \\
\hline & 1 & 2 & 2,5 & 3 & 1 & 1,5 & 2 & 2,5 & 3 \\
\hline C 12/15 & 0,193 & 0,199 & 0,208 & 0,219 & 0,233 & 0,328 & 0,334 & 0,342 & 0,351 & 0,362 \\
\hline C 16/20 & 0,191 & 0,197 & 0,206 & 0,217 & 0,231 & 0,325 & 0,331 & 0,338 & 0,347 & 0,358 \\
\hline BOL 9 & 0,223 & 0,230 & 0,238 & 0,250 & 0,264 & 0,378 & 0,384 & 0,391 & 0,401 & 0,412 \\
\hline BOL 15 & 0,197 & 0,204 & 0,212 & 0,223 & 0,237 & 0,325 & 0,340 & 0,348 & 0,357 & 0,368 \\
\hline
\end{tabular}

Istraživanjem je ustanovljeno da vanjski kratki stupovi okvira s djelomičnim ispunom od nekonvencionalnog betona imaju do 11,3\% manju poprečnu silu u odnosu na vanjske kratke stupove okvira s djelomičnim ispunom od konvencionalnih betona (slika 6a). Poprečna sila unutarnjih stupova okvira s djelomičnim ispunom od nekonvencionalnog betona je do $5,8 \%$ manja u odnosu na poprečnu silu unutarnjih kratkih stupova okvira $\mathrm{s}$ djelomičnim ispunom od konvencionalnih betona (slika 6b).

Kod svih vanjskih stupova okvira razmatranih ovim radom, uočeno je povećanje poprečne sile $s$ povećanjem posmične vitkosti (slika 6a).

Za razliku od vanjskih stupova, kod unutarnjih stupova ovaj trend je znatno drugačiji. Poprečna sila se kod unutarnjih stupova okvira visine četiri kata smanjuje do posmične vitkosti stupa $\alpha_{\mathrm{s}}=2$, nakon čega slijedi njen postepeni porast, no poprečna sila unutarnjih stupova okvira visine sedam katova postepeno se smanjuje $s$ povećanjem posmične vitkosti (slika $6 b$ ).

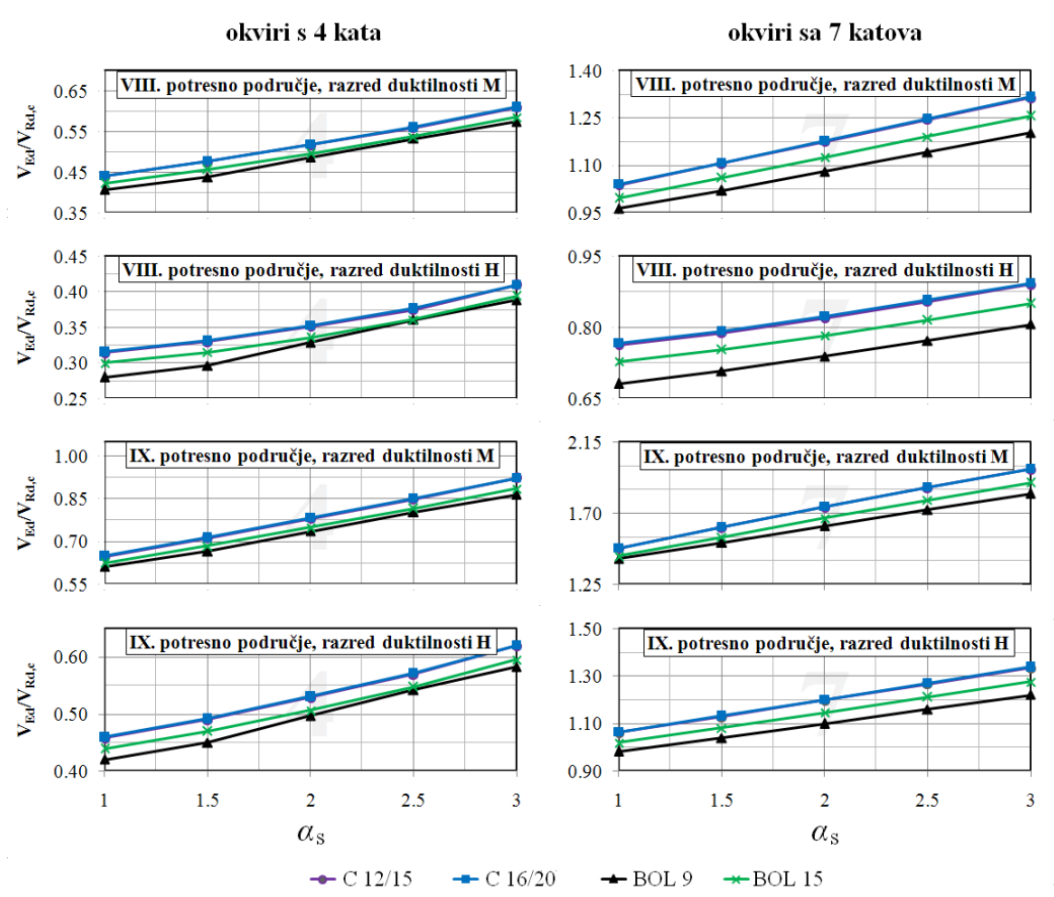

a) 
okviri s 4 kata
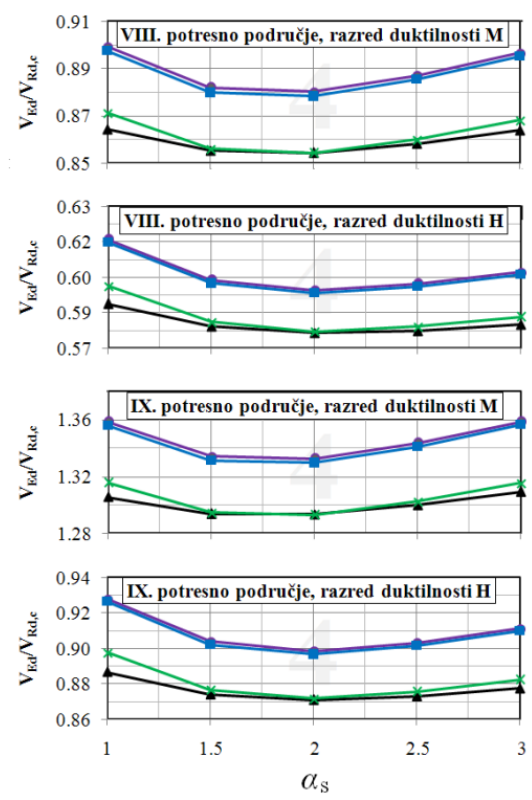

okviri sa 7 katova
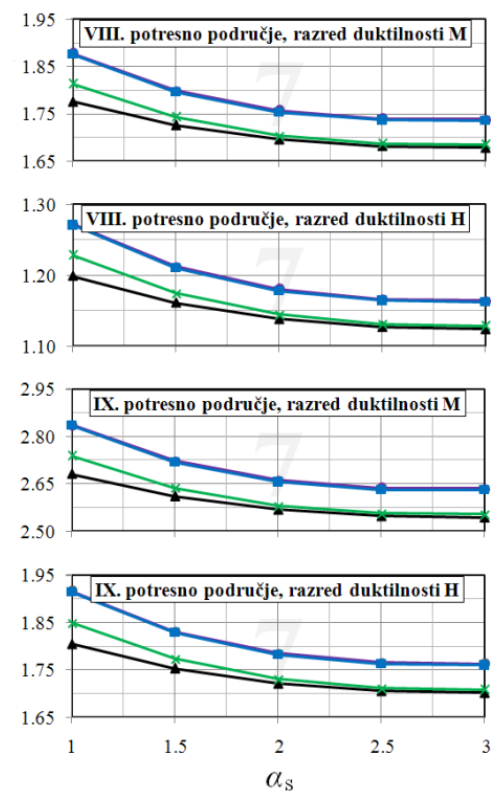

$\rightarrow \mathrm{C}_{12} / 15 \rightarrow \mathrm{C} 16 / 20 \neq \mathrm{BOL} 9 \neq \mathrm{BOL} 15$

b)

Slika 6 - Omjer proračunske poprečne sile $V_{\mathrm{Ed}}$ i proračunske nosivosti na poprečnu silu presjeka elementa bez poprečne armature $V_{\mathrm{Rd}, c}$, ovisno o posmičnoj vitkosti kratkog stupa $\alpha_{s}$ za: a) vanjski stup; b) unutarnji stup

Istraživanje je potvrdilo početnu pretpostavku o povoljnom utjecaju ispuna od betona s opekarskim lomom u sastavu na potresni odziv kratkih stupova, ne samo zbog smanjenja poprečne sile, već i zbog smanjenja potrebne količine uzdužne armature dijagonalnih koševa vanjskih kratkih stupova do 7,9\% i unutarnjih kratkih stupova do 4,6\% (slika 7).
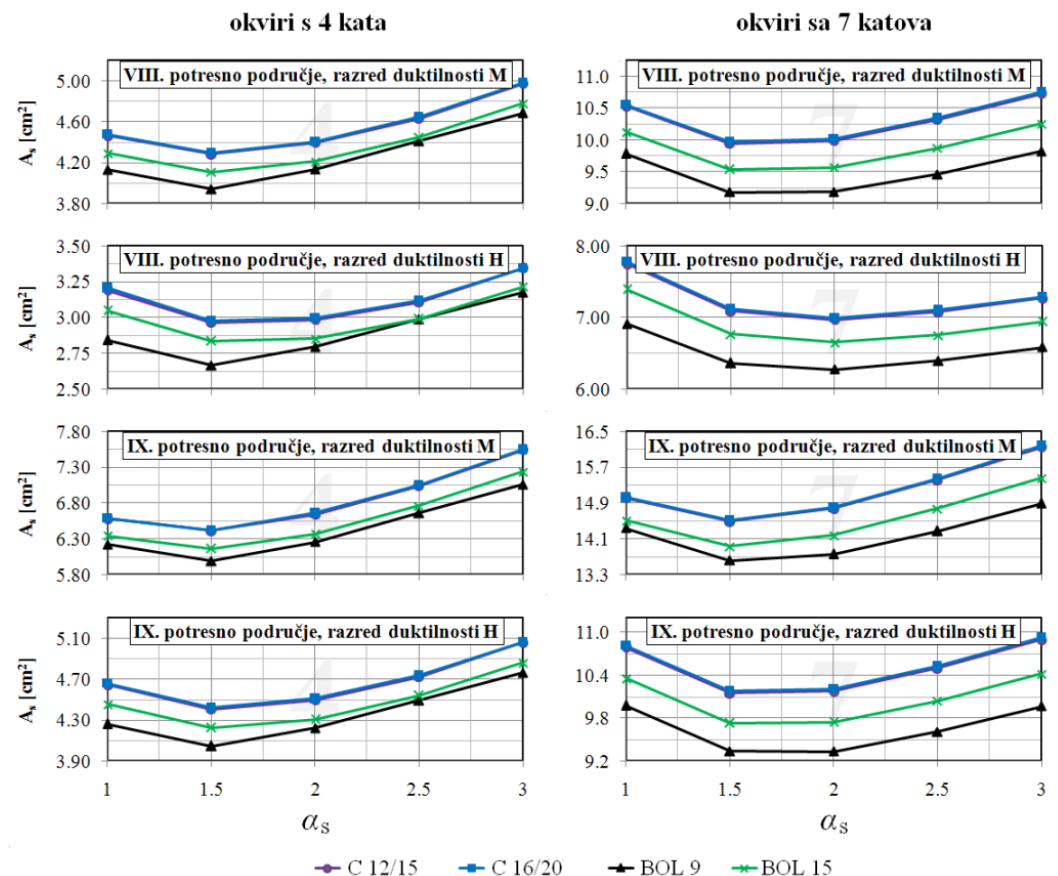

a) 
okviri s 4 kata
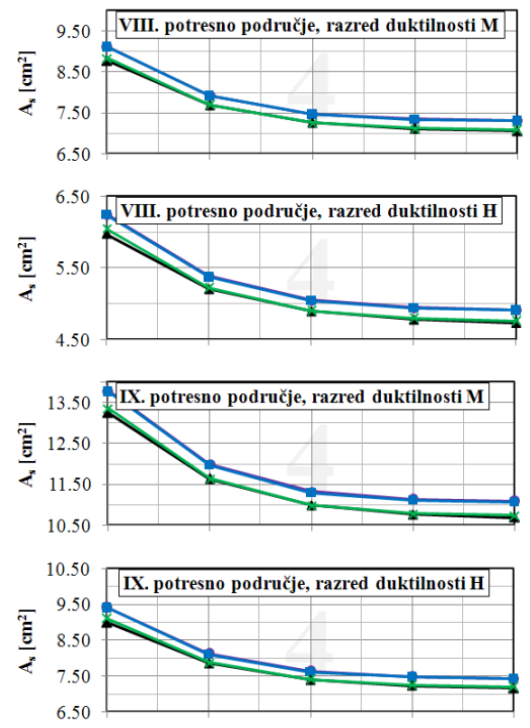

$\alpha_{\mathrm{S}}$ okviri sa 7 katova
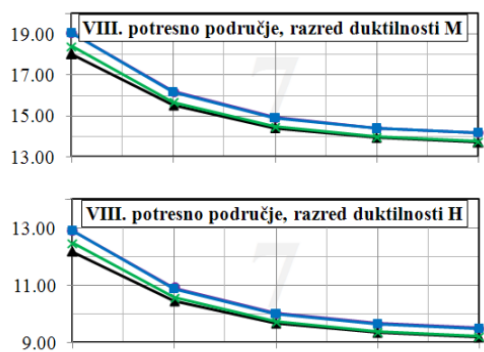

30.00 IX. potresno područje, razred duktilnosti M

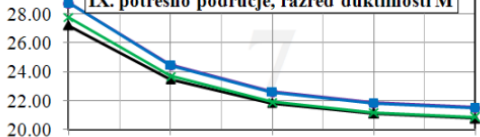

21.00 IX. potresno područje, razred duktilnosti $H$

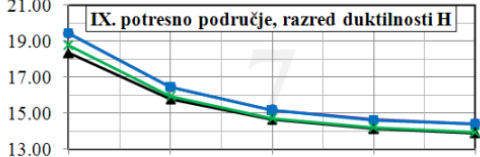

$\alpha_{\mathrm{S}}$

$\rightarrow \mathrm{C} 12 / 15 \rightarrow \mathrm{C} 16 / 20 \rightarrow \mathrm{BOL} 9 \rightarrow \mathrm{BOL} 15$

b)

Slika 7 - Potrebna količina uzdužne armature dijagonalnog koša kratkog stupa $A_{\mathrm{s}}$, ovisno o njegovoj posmičnoj vitkosti $a_{s} z a:$ a) vanjski stup; b) unutarnji stup

Nadalje, zamjena konvencionalnog betona betonom s opekarskim lomom u sastavu, vodi k izraženijem smanjenju potrebne količine uzdužne armature dijagonalnih koševa kod vanjskih kratkih stupova s posmičnom vitkosti $a_{\mathrm{s}}<2$ (slika 7a). Osim toga, kod unutarnjih kratkih stupova uočeno je da se potreba za ugradnjom uzdužne armature dijagonalnih koševa postepeno smanjuje s povećanjem posmične vitkosti (slika $7 \mathrm{~b}$ ).

Kod vanjskih kratkih stupova uočeno je da se potreba za ugradnjom uzdužne armature dijagonalnih koševa smanjuje do posmične vitkosti $\alpha_{s}=1,5$, nakon čega se ona postepeno povećava (slika 7a). Iznimka je uočena jedino kod vanjskih kratkih stupova okvira izdvojenog iz zgrade visine sedam katova, smještene u VIII. potresnom području i visokog razreda duktilnosti. Tamo je uočeno da se potreba za ugradnjom uzdužne armature dijagonalnih koševa smanjuje do posmične vitkosti $\alpha_{s}=2$, nakon čega se ona postepeno povećava (slika 7a).

\section{Zaključak}

Numerička studija o ponašanju kratkih stupova zbog djelovanja potresnog opterećenja izvršena je na tropoljnim, ravninskim, armiranobetonskim okvirima visine četiri i sedam katova, $s$ djelomičnim ispunom od različitih vrsta betona. U istraživanju, a za izvedbu djelomičnih ispuna okvira, korištene su dvije vrste običnog betona i dvije vrste nekonvencionalnog betona s keramičkim lomom u sastavu, svi s relativno niskom tlačnom čvrstoćom.

Izvedba djelomičnih ispuna okvira s betonom u čijem je sastavu prirodni agregat djelomice zamijenjen opekarskim lomom, vodi ka smanjenju poprečnih sila kratkih stupova do 11,3\%. Osim toga, primjena ovih betona za izvedbu djelomičnih ispuna okvira stvara manju potrebu za ugradnjom uzdužne armature u dijagonalne koševe i to do $7,9 \%$. Između ostalog, zbog male specifične gustoće opekarskog loma u odnosu na prirodni agregat, takav beton ima manju specifičnu težinu te je stoga povoljan za izvedbu nenosivih dijelova konstrukcija koje se grade u potresno aktivnim područjima.

Primjenom betona s opekarskim lomom reducirala bi se potreba za količinom ugrađene armature $u$ armiranobetonske elemente i umanjila oštećenja konstrukcija zbog djelovanja potresa. Također bi se smanjila potreba za eksploatacijom prirodnih sirovina, a nekontrolirano odlaganje otpada nastalog pri proizvodnji crijepa i opeke svelo bi se na najmanju moguću mjeru. Smanjenom potrebom za armaturom i prirodnim agregatom djelujemo prvenstveno na očuvanje okoliša te osiguranje održivog gospodarenja građevinskim otpadom. 
Da bi se potvrdili ili opovrgnuli rezultati ovog istraživanja, potrebno je provesti dodatne numeričke studije i eksperimentalna ispitivanja na stvarnim konstrukcijama.

\section{Literatura}

[1] Multidisciplinary Center for Earthquake Engineering Research (MCEER) at University of Buffalo, 1999. Failure of column, due to short column effect, of a 5-storey building in Ano Liosia, which was built in 1997 according to the new Greek Seismic Code. [slika online] dostupno na: http://mceer.buffalo.edu/research/Reconnaissance/greece9-7-99/fig_5.asp, pregledano 26.7.2012.

[2] Fierro, E., 2001. Short column at another school in Camana. [slika online] dostupno na: http://www.eeri.org/2001/06/southern-peru/, pregledano 26.7.2012.

[3] Guevara, L. T., Garcia, L. E., 2005. The captive- and short-column effects. Earthquake Spectra, volumen 21, broj 1, pp 141-160. [online] dostupno na: http://15wceess.blogspot.com/2012/05/captive-and-shortcolumn-effects.html, pregledano 11.5.2012.

[4] Tomičić, I., 2009. Proračun i konstruiranje kratkih armiranobetonskih stupova. Građevinar, volumen 62, broj 8, pp 717-722. [online] dostupno na: http://www.casopis-gradjevinar.hr/arhiva/article/279, pregledano 11.5.2012.

[5] Sigmund, V., Zlatović, S., 2000. Nedavni veliki potresi i njihovo značenje, Građevinar, volumen 52, broj 11, pp 695-703. [online] dostupno na: http://hrcak.srce.hr/file/20015, pregledano 15.9.2012.

[6] Kesegić, I., Bjegović, D., Netinger, I., 2009. Upotreba reciklirane opeke kao agregata za beton, Građevinar, volume 61, broj 1, pp. 15-22. [online] dostupno na: hrcak.srce.hr/file/56136, pregledano 27.8.2012.

[7] Kesegić, I., Netinger, I., Bjegović, D., 2008. Recycled clay brick as an aggregate for concrete: overview, Tehnički vjesnik, volumen 15, broj 3, pp. 35-40. [online] dostupno na: hrcak.srce.hr/file/44759, pregledano 27.8.2012.

[8] CEN - European Committee for Standardization (2004). Eurocode 8 - Design of structures for earthquake resistance - Part 1: General rules, seismic actions and rules for buildings

[9] SAP2000, verzija 14.1.0. Programski paket za statički i dinamički proračun konstrukcija. Pacific Earthquake Engineering Research Center, University of California, Berkeley, California

[10] Tomičić, I., 1996. Betonske konstrukcije (3. izdanje), Društvo hrvatskih građevinskih konstruktora, Zagreb

[11] CEN - European Committee for Standardization (2004). Eurocode 2 - Design of concrete structures - Part 1-1: General rules and rules for buildings

[12] Konstantinidis, A., 2008. Earthquake resistant buildings from reinforced concrete, Volume A - The art of construction and the detailing. Athens, [online] dostupno na: http://www.pi.gr/CMSnew/index.php, pregledano 23.5.2012.

[13] CEN - European Committee for Standardization (2002). Eurocode 1 - Actions on structures - Part 1-1: General actions - Densities, self-weight, imposed loads for buildings

[14] Kraus I., Morić, D. Netinger, I., 2011. Usporedba potresnog odziva armiranobetonskih zgrada od nekonvencionalnih betona. Elektronički časopis e-GFOS, broj 3 - prosinac, pp 1-13. [online] dostupno na: http://e-gfos.gfos.hr/en/index.php/archive/number-3, pregledano 23.5.2012.

[15] Sigmund, V. i drugi, 2000. Usporedba seizmičkog proračuna prema hrvatskim propisima i Eurokodu 8. Građevinar, volumen 52, broj 7, pp 379-388. [online] dostupno na: http://www.casopisgradjevinar.hr/arhiva/article/77, pregledano 17.7.2012. 